\title{
Artistic Factor in Modern-Day Urban Planning and Design in Lithuania
}

\author{
Dalia Dijokienè, Vilnius Gediminas Technical University \\ Agnè Vètè, Vilnius Gediminas Technical University
}

\begin{abstract}
The issue of city modelling is very essential these days and it is important to analyse the legal framework and its practical implications in the process of city modelling. However, the practice of urban design in Lithuania is based on two-dimensional solutions and the artistic factor is overlooked. The article reviews the legal basis of Lithuanian urban planning and design and their practical implications and emphasizes the necessity of artistic factor during the process of city modelling.
\end{abstract}

Keywords - Urban planning and design in Lithuania, city modelling, legal framework, artistic tools.

\section{INTRODUCTION}

The academic field of urban design and urban planning and gaps of their practical implications are widely discussed in Lithuania [3]-[5], [8], [26], [27]. Even though the academic society of Lithuania agrees on the significance of city identity, preservation of historical core and other three-dimensional questions in city modelling, the practice of urban design is based on two-dimensional issues in Lithuania. There are no laws of architecture, urban design or urban planning in Lithuanian legal system. However, the need of these laws can be defined by the main territorial planning law in Lithuania, which does not include all the issues of urban design and urban planning. In the Law on Territorial Planning it is possible to find only the definitions of issues which deal with three-dimensional parameters and artistic factor: urban structure, spatial structure, arrangement of spaces [13]. Though, none of these definitions is explained in the law.

Even so, according to the Law on Territorial Planning, the concept of the city master plan should consist of three parts: general spatial concept, determination of functional priorities, peculiarities of territories regulations [12]. It could be assumed that general spatial concept should deal with three-dimensional artistic factor questions, but the law does not explain how to implement this concept. Also, the practical examples of master plans of Lithuanian cities illustrate the inability of the Law of Territorial Planning to take in all urban issues: usually there are no drawings or schemes, which represent the system of urban public spaces, city silhouette and panoramas, urban composition, urban form, etc. [7].

However, despite the limitation of Lithuanian legal framework and lack of practical traditions of urban design and urban planning in Lithuania, the issue of city modelling and nurturance of city uniqueness are still crucial questions. Therefore, not only the Lithuanian legal framework, but also practical results in Lithuania need to be analysed. The presented research is based on the statistical analysis method and was carried out according to the following stages:

- The review of artistic tools in urban design;

- The survey of relevant legal framework and valid city master plans in Lithuania;

- The determination of dominants of city general spatial concept in Lithuania;

- The identification of prevailing understanding of city general spatial concept in Lithuanian practice.

The article presents the basic results of the research and proposes conclusions for the future explorations.

\section{Artistic Tools In Urban Planning And Design}

According to the Lithuanian territorial planning law, only a person with the degree in Architecture can be the manager of a city master plan [13]. Based on this fact it could be said that the city master plan is the legal document, which should also include the issues of architectural development.

Urban design and urban planning in Lithuania are perceived differently in various architecture, urban design and urban planning related legal documents. According to the Architectural Policy document of the Republic of Lithuania, the definition of urbanistika (in Lithuanian the term urbanistika refers to both urban design and planning) involves not only the smallest settlement but also a big city - it is an architectural whole developed in the space, which consists of buildings for various purposes and interrelated structure of facilities: streets, bridges, tunnels, squares, parks, shaped natural environment [17]. In other words, it defines an architect's work which can be entitled as urban design. The career, described in the Urban Policy Project of the Republic of Lithuania, should be called urbanistika or town planning, which covers more than the degree in Architecture [14]. Nevertheless, the definitions urban design and urban planning are related and the dividing line between them distinguishes the architectural work based on the formation of spaces by artistic factor principles from the field of activity where social and economic issues become dominant [3]. Urban design is an integral part of the art and science of architecture and its indispensable field of activity. It is closely linked to urban planning and architecture. While urban planning focuses more on systemic urban pattern issues and architecture - on very concrete volumetric tasks, urban design brings those two disciplines together under the concept of urban space [15]. The object of urban design is spatial urban structures, 

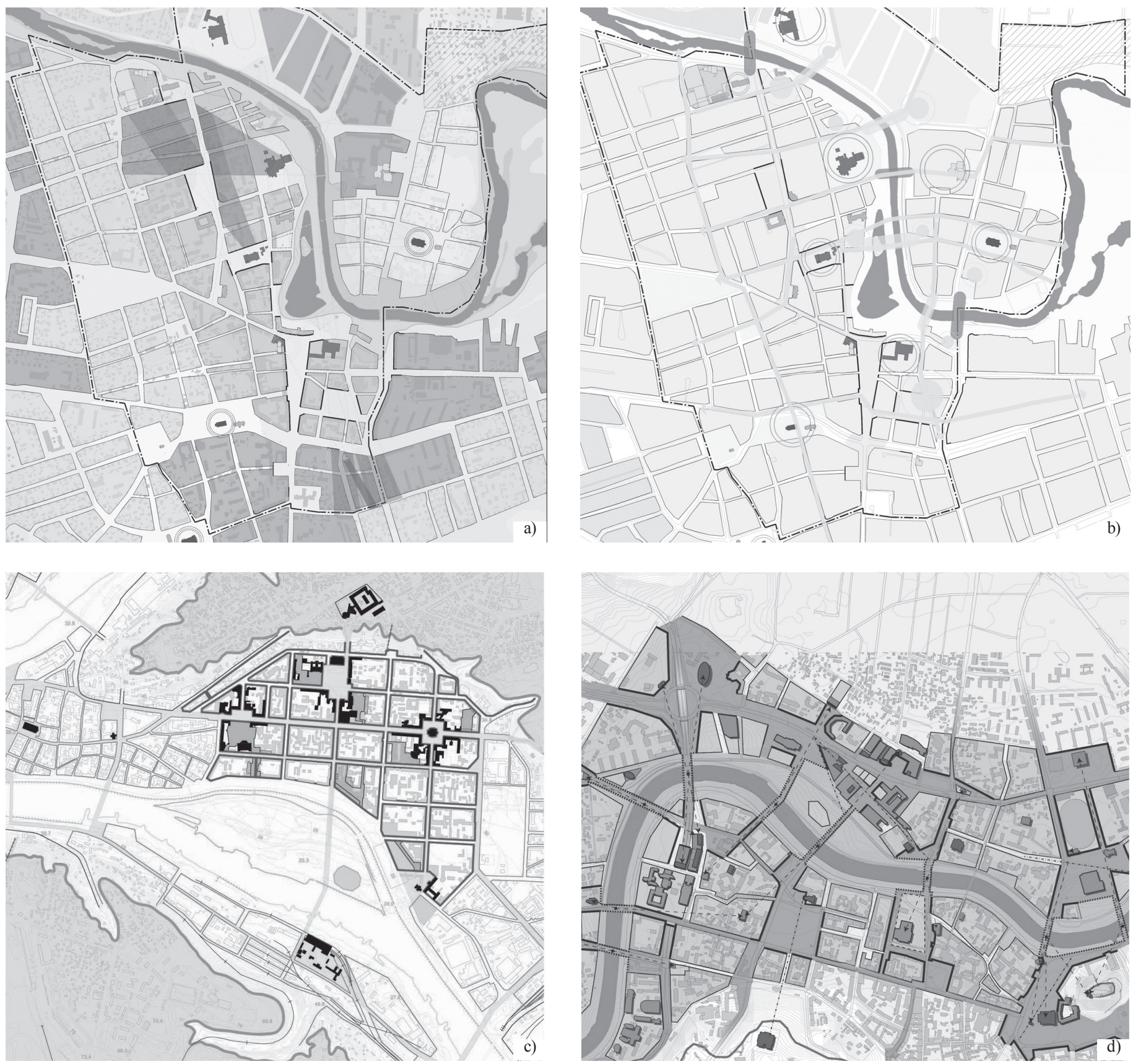

Fig. 1. Fragments of final works of master students of the Department of Urban Design of VGTU Faculty of Architecture (Pictures: a, b - M.Čiurlyte, 2014 [2], c T.Skripkiūnas, 2014 [21], d - K.Sujetaitè, 2016 [22].

for instance, morphotypes of built-up in blocks, public urban spaces (squares and their systems), townscapes, positioning of landmarks, etc. The field of architectural activity is closer to the field of urban design than to urban planning, but in order to solve urban planning problems the architectural knowledge and skills are necessary.

When designing urban fabric, we should take into account not only time series of a town or city but also form series. Urban designers aim to create high-quality urban fabric, which depends on the factors affecting functionality, aesthetics and durability.
Of all the qualities of cities, arguably the one that concerns us most is the nature of the aesthetic experience [1]. What makes a city beautiful? This, of course, is a vast question. Urban design generally follows the established rules of proportions, for example when establishing the dimensions of districts and building lots, streets, squares and open spaces, in plan as well as in section, or even in defining the proportions of streets or buildings in terms of width, depth, and height. Nonetheless, the use of harmonious proportions in design is not a recipe for success [20]. Urban design projects may be created following the principles of abstract 


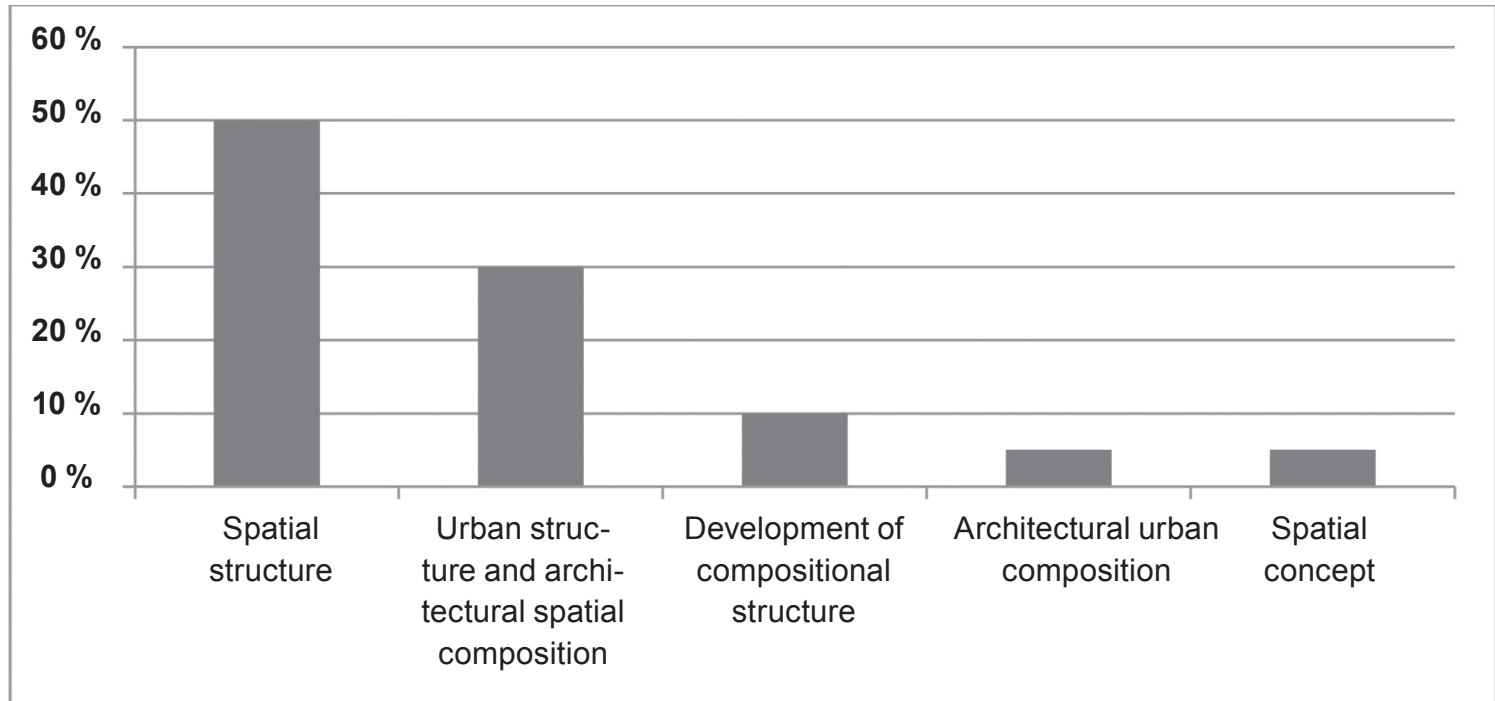

Fig. 2. The frequency of terms used for general spatial concept in analysed city master plans in Lithuania [24].

composition, mathematical calculation, contextuality, rationality, and others.

The Department of Urban Design of Vilnius Gediminas Technical University (VGTU) represents scientific and academic position of urban design in Lithuania and has the traditions of over 70 years (the date of establishment is considered to be 1944). The Department, which is part of the Faculty of Architecture, has always applied the European disciplinary concept. Students of the Faculty of Architecture of VGTU have Introduction to Urban Design as part of their architectural curriculum in their second, third and fourth year of studies, consisting of theory lectures and project tasks. Master studies are devoted to cultivating the excellence in the field (see Fig. 1). The well-known Lithuanian scientists, such as K. Šešelgis, A. Miškinis, J. Vanagas, P. Juškevičius, Z. J. Daunora, A. Vyšniūnas, V. Jurkštas, I. Alistratovaitė-Kurtinaitienè, D. Dijokienè, agree on the significance of plan, view the relation in the process of city modelling and recognize urban composition as the main artistic tool in urban planning and urban design [25]. Moreover, Lithuanian academicians appeal to Western scientific literature and emphasize the relevancy of space and their systems in cities [10], [18], [19]. For example, R. Trancik suggested that integrated urban design principles are one of the methods used in urban design and urban planning studies [23].

Even though Lithuanian academic society conceives the fields of urban design and planning as not dissociative from artistic factors, the tendency in practical implications is different.

\section{Modern-Day Urban Planning And Design In Lithuania}

\section{A. The Review of Relevant Legal Framework and Valid City Master Plans in Lithuania}

As it was mentioned previously, the Law on Territorial Planning is the main law in Lithuania which defines the development of city master plans and their concepts. There were three main changes in this law: the first one was inured in 1995; the secondin 2004; and the third one, which is valid now, in 2013. Also, the Rules of town and city master plan development, which were changed alongside with the territorial planning law (the first Rules were inured in 2004; the second, which are valid now, in 2014), are significant in the process of the development of city master plans [9], [11]-[13], [16].

Comparing the main existing relevant valid legal documents, the following presumptions are suggested:

- The previous territorial planning law (inured in 2004) determined the need for a city master plan concept including the general spatial concept. The new territorial planning law (inured in 2013) does not define the necessity of the city master plan concept. Thereby, there is a presumption that a city master plan will involve less three-dimensional issues and coherent city modelling in future;

- Even though, the old and the new territorial planning laws apply various definitions, which are relevant to three-dimensional and artistic issues, most of them are not determined. It may lead to different interpretations of definitions;

- The new territorial planning law (inured in 2013) gives more freedom to local municipalities during the process of city master plan development. However, the inaccuracy and ambiguity of legal framework may lead to poor quality of city master plans;

- $\quad$ Although the new territorial planning law (inured in 2013) involves more city modelling related definitions, such as public urban spaces or building morphotypes, only the old territorial planning law (inured in 2004) required to prepare general spatial concept where spatial morphostructure elements were discussed. Consequently, the two-dimensional planning will become more predominant in Lithuania. 


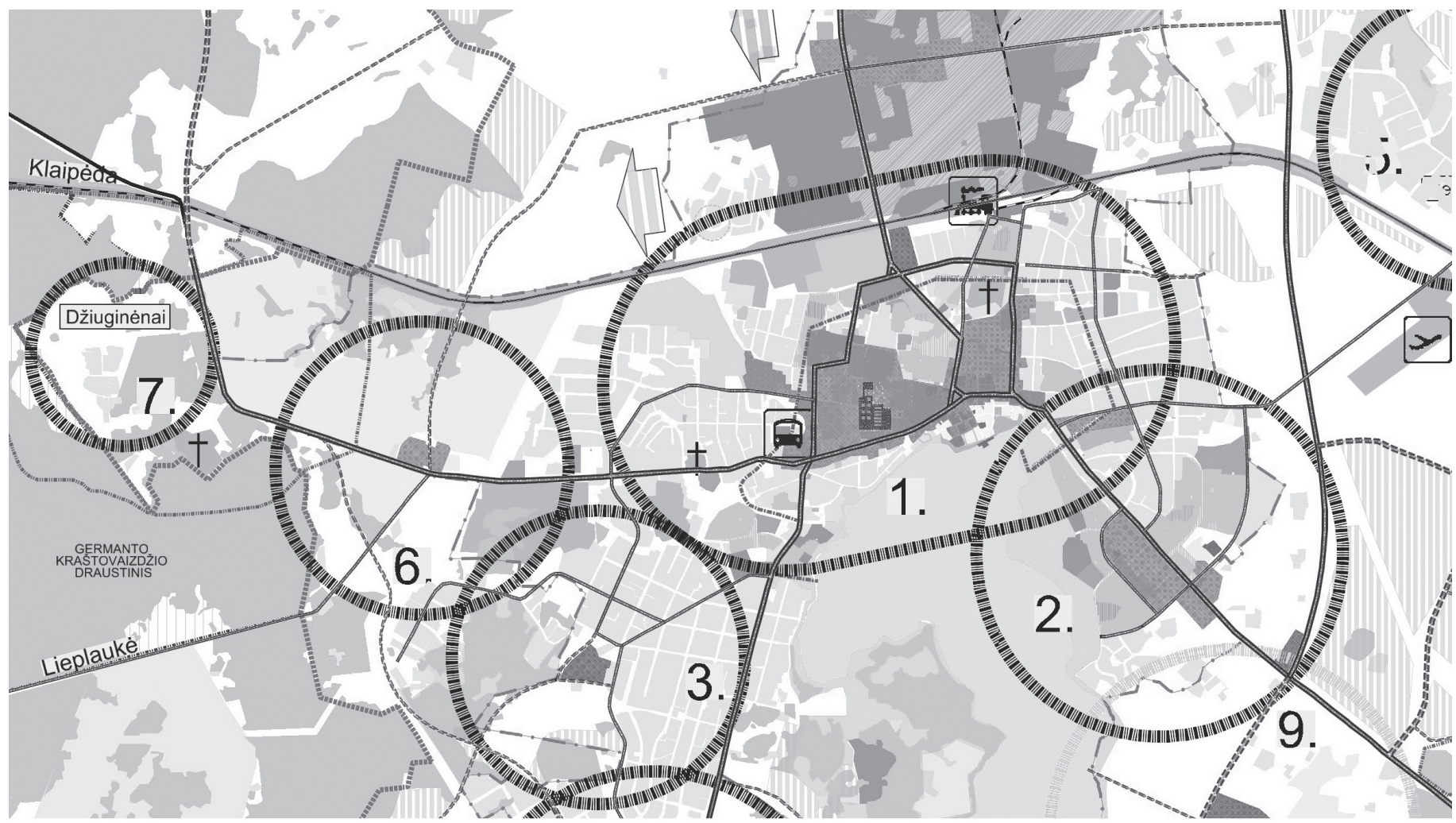

Arbitrary signs
Forests
Water surfaces
Garden allotments
Cultural heritage sites
Existing residential areas - low-rise buildings
Existing residential areas - high-rise buildings
Existing commercial use areas
Existing public use areas
Industrial, storage use areas
Engineering infrastructure areas
Areas left for national defence
Recreational areas
Greenery development zone
Underlying commercial areas
Underlying industrial areas

Direction of possible development of residential areas
Direction of possible development of industrial areas
Pxisting local residential districts
Planned local residential districts
The structure of existing main streets
The development of streets structure
Existing boundaries of town
Planned boundaries of town
The administrative node
Railway station
Airport

Fig. 3. An example of general spatial concept drawing of Telsiai city master plan: dominating functional issues (source: http://www.telsiai.lt/BP/?p=p_36).

City master plans, which are valid now, were enacted during the validity of the previous territorial planning law (inured in 2004). As a result, the implications of the new territorial planning law (inured in 2013) in city master plans cannot be checked in practice yet. In order to make a comprehensive and impartial research, all of the valid Lithuanian city master plans were reviewed. There are 103 cities in Lithuania and only 74 valid city master plans (the data are according to the situation as of November 2015). It means that $28.2 \%$ of all Lithuanian cities do not have a valid master plan. The research revealed that only 20 city master plan concepts are publicly available - less than the third of concepts are publicized in full. It means that local municipalities and society do not give enough credit to the concept of city master plan. It is a paradox because according to the legal documents the conceptual part of city master plan is even more important than the solutions part - the concept is valid for 20 years and the solutions are valid only for 10 years [12].

However, the key issue in the research was the question of artistic factor in urban planning which could be found in general spatial concepts of city master plans. In order to identify the understanding of general spatial concept of master plans of cities, the research focuses on general spatial concepts of valid and publicly available master plans of all cities of Lithuania - altogether 20 documents. 


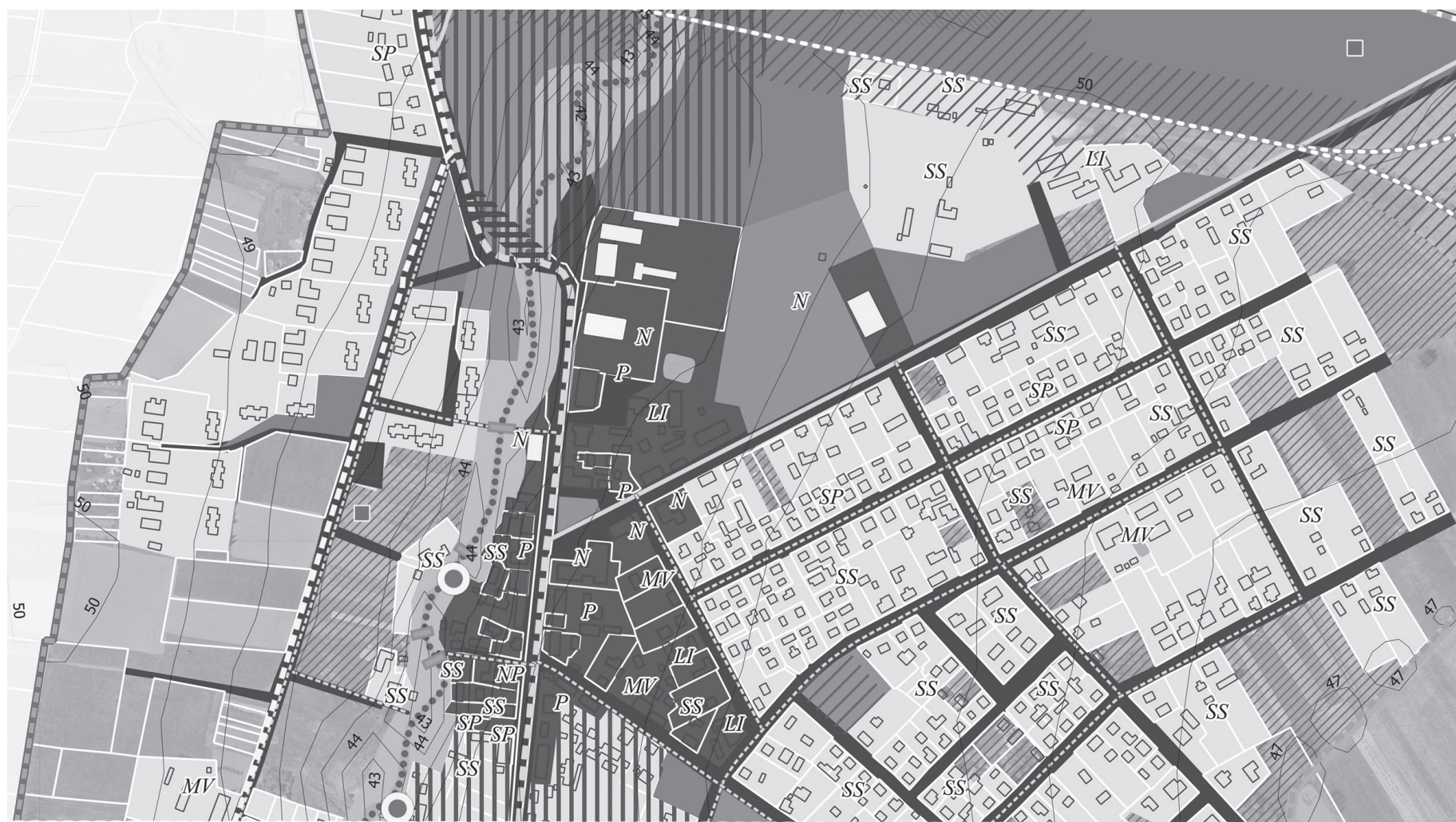

Arbitrary signs

Blocks structures

Existing blocks structures

UII/, Planned blocks structures

Territories of the town compositional core

The existing compositional town core

Disconnected parts of compositional core

IIII Newly formed compositional links between nodes

Other compositional elements

The most important existing dominants

Existing local dominants

- Planned local dominants

The net of streets (compositional town framework)

- - The natural compositional axis

Public urban spaces

Commonly used spaces (squares, parks, cemetaries, stadiums)

Recreational segments of the town

Regional cycleways

Cycleway for cognitive recreation

$+=\omega-$ Cycleways and pathways for local residents

(O) Planned approaches to the water

Cultural heritage sites

//, Cultural heritage sites

The sub-zone of visual protection zone

ar. The narrow-gauge railway

Other signs

$\square$ Buildings

Planned bridges

Other undeveloped territories (except agricultural)

The open green river space

The river "Mažupè"

Fig. 4. The example of general spatial concept drawing of Joniskelis town master plan: rare case with references to artistic factor and three-dimensional issues (source: http://www.pasvalys.lt/downloads/Bendrasis\%20planas/Joniskelio_m_bendrasis_planas.zip).

\section{B. The Determination of Dominant in General Spatial Concept of Cities in Lithuania}

Although, the legal documents determine that general spatial concept is a part of city master plan concept, other terms are used more often (see Fig. 2). It shows that usually in Lithuanian practice general spatial concept is understood as a spatial structure.

The analysis of drawings of general spatial concepts of city master plans did not include the basic elements of existing situation such as: administrative boundaries, roads, streets, bridges, railways, water surfaces, forests and other natural framework, cemetery, various protected areas. These elements do not depend on the type of drawing. Consequently, the groups of elements which are used to express general spatial concept were identified:

- Functional zones (public, residential, industrial, commercial, recreational, etc. zones);

- Axes (functional axes, urban axes, structural axes - usually they are the same as a street middle line); 
- Main public objects (bus and railway stations, schools, hospitals, other objects which usually are marked as logos);

- Development types (high or low building intensity rate; industrial, commercial, recreational and etc. territories);

- Elements of city composition (building intensity rate, historical core, greenery, the most important recreational areas, etc.);

- Functional nodes (central, local);

- Main purposes and uses of land;

- Spatial structure (residential, commercial and other areas; greenery elements, etc.);

- Main natural components (relief, forests, water surfaces, shrubbery, etc.);

- Exceptional elements (rarely used in drawings): system of nodes, structure of blocks, public spaces, building morphotypes, landmarks, visual viewpoints.

Considering the identified groups of elements above, the implication is that functional elements are widely used: functional zones, main public objects, functional nodes, main purposes and uses of land. Also the attention is paid to natural elements. Moreover, despite the fact that there is a separate functional priorities drawing, functional elements are used more often than others in general spatial concept drawings: mostly functional zones (45 \% of drawings) and main public objects (30\% of drawings) are marked in general spatial concept drawings; there are less than $20 \%$ general spatial concept drawings where it is possible to find elements related to three-dimensional issues. Furthermore, main purposes and uses of land are applied three times more often than such elements as blocks, building morphotypes, public spaces. In addition to this, only $15 \%$ of analysed general spatial concept drawings do not include functional elements, which are presented in functional priorities drawing.

However, the analysis of general spatial concept drawings shows that there are some references to artistic factors and three-dimensional issues in Lithuanian practice. According to the more detailed analysis of elements used in general spatial concept drawings (the basic elements of existing situation and function related elements are distinguished), it may be stated that general spatial concept can be described by these elements in rare cases in Lithuanian practice:

- Building intensity rate;

- Structural parts of city (city nodes, historical core, neighbourhood, etc.);

- Compositional cores and links between them;

- Visual viewpoints and zones;

- Main natural components;

- Hierarchy of landmarks;

- Block structures;

- Building morphotypes;

- Urban public spaces.

Unfortunately, the appearance of these elements in general spatial concept drawings is rare. The research of general spatial concept includes not only drawings, but also explanatory notes of valid city master plans in Lithuania. At first glance it seems that usually $10-25 \%$ of explanatory notes are dedicated to general spatial concept issues. Even though there is a chapter of spatial concept, usually it consists of functional, social, communication, engineering infrastructure questions. So generally 1-5 \% (or even less) of explanatory notes are about spatial concept, spatial structure or other three-dimensional and artistic factor related issues.

The research of general spatial concepts of city master plans presents the predominance of functional issues in Lithuanian urban planning and design practice. In summary, even though the law determines that there are two main parts of city master plan concept - functional priorities and general spatial conceptusually only functional issues are discussed (Fig. 3), (Fig. 4). This conclusion indicates the gap not only in the legal system of Lithuanian urban planning and design but also the lack of perception of three-dimensional issues and artistic factor in Lithuanian urban design practice.

\section{Conclusion}

The perception of artistic principles as tools for urban design and urban planning is taught and implemented in Lithuanian schools of architecture. On the basis of the projects of bachelor and master students of the Department of Urban Design of VGTU Faculty of Architecture, it may be stated that the young generation of architects is not only interested in innovative design but also aims to understand and incorporate in their projects the established features of physical form of town [6].

Considering the legal framework of urban planning and design and its practical implications, it could be said that it depends on the theory which is recognized in the particular country and schools which prepare specialists. However, the research results showed that in Lithuanian urban design three-dimensional artistic questions usually are replaced by functional parameters and issues. The review and analysis of general spatial concepts of cities and relevant legal framework presented the perception of general spatial concept in Lithuanian urban design practice, which may be generalized as follows:

- The lack of definitions and their determinations in Lithuanian legal framework reflects on urban design practice: heterogeneous substance of drawings and explanatory notes; different perception and interpretation of definitions and concepts;

- Due to the confusion and interpretation of definitions, the idea of general spatial concept can hardly be determined in Lithuanian urban design practice. Though, the trend of the development of general spatial concept is perceptible: the general spatial concept mostly is understood as the solution of functional issues. Only $15 \%$ of analysed general spatial concept drawings of city master plans do not deal directly with functional problems and the dominance of functional issues in their explanatory notes is even clearer;

- Although, commonly city general spatial concept is understood as two-dimensional, there are some references to three-dimensional and artistic issues in Lithuanian urban design practice. In rare cases it is possible to find these 
elements in city general spatial concept: city historical core, compositional nodes and links between them, visual viewpoints and zones, building intensity rate, natural components, greenery structure, building morphotypes, urban public spaces.

The accomplished research presents that in Lithuania the existing legal framework of urban planning and design is missing the artistic factor. In order to solve the problem of absence of three-dimensional artistic questions in urban design, the scientific basis must be strengthened and used as the means for improving the legal framework of urban planning and design and its practical implementation in Lithuania.

\section{REFERENCES}

1. Cuthber, R. A. The form of cities. Political economy and urban design Malden, Oxford, Carlton: Blackwell Publishing, 2006. 324 p.

2. Čiurlytė, M. Panevėžio centrinès dalies urbanistinių erdvių sistemos urbanistinė architektūrinė koncepcija / Urban Architectural Concept of the Urban Spaces System in the Central part of Panevežys [final work of master's studies of architecture, tutor A. Vyšniūnas]. Vilnius: VGTU 2014.

3. Daunora, Z. J. Urbanistikos mokslo ir studiju vietos Lietuvos klasifikatoriuose paradoksai. Town planning and Architecture, Vol. 32(4) 2008 , pp. 221-231. https://doi.org/10.3846/1392-1630.2008.32.221-231

4. Daunora, Z. J. Regioninio konteksto prioritetai Kazio Šešelgio urbanistinèje Lietuvos miestų plètros strategijoje. Miesto architektūra. Erdvès, formantai, akcentai [articles collection]. Vilnius: VDA 2015, pp. 35-51.

5. Dijokienè, D. Urbanistikos meno ir mokslo reikšmè architektūros studiju programoje. Town planning and Architecture, Vol. 37(4) 2013, pp. 268-278. https://doi.org/10.3846/20297955.2013.866822

6. Dijokiene, D. Challenges of designing new urban quality in historical environment: based on final projects of BA students of the Department of Urban Design, FA, VGTU. Architecture and urban planning, Vol. 82013 , pp. 60-64. https://doi.org/10.7250/aup.2013.021

7. Ivanauskaité, A. Miesto urbanistinès formos samprata ir jos taikymo galimybės Lietuvoje. Science - future of Lithuania, Vol. 7(1) 2015, pp. 46-54.

8. Juškevičius, P. Lietuvos miestų sistemos raida ir jos ateities perspektyvos. Miesto architektūra. Erdvès, formantai, akcentai [articles collection]. Vilnius: VDA 2015, pp. 11-34.

9. Kompleksinio teritorijų planavimo dokumentų rengimo taisyklès [online] 2014-01-02 Nr. D1- 8 [cited 10.11.2015]. http://www.am.lt/VI/files/File/ TPUAD/TP\%20nauji/Taisytos\%20-\%20Kompleksinio\%20teritoriju\%20 planavimo\%20dokumentu\%20rengimo\%20taisykles.pdf

10. Landa, F. Actual changes in system of urban planning in post-socialist city: the case of Prague. Journal of architecture and urbanism, Vol. 40(4), 2016, pp. 303-310. https://doi.org/10.3846/20297955.2016.1246986

11. Lietuvos teritorijų planavimo ịstatymas [online]. 1995-12-12 Nr. I-1120 [cited 10.11.2015]. https://www.e-tar.lt/portal/lt/legalAct/TAR.26B563184529

12. Lietuvos teritorijų planavimo įstatymo keitimo ịstatymas [online]. 200401-15 Nr. IX-1962 [cited 10.11.2015]. https://www.e-tar.lt/portal/lt/lega1Act/TAR.1C65A214E386

13. Lietuvos teritorijų planavimo ịstatymo keitimo ịstatymas [online]. 201306-27 Nr. XII-407 [cited 10.11.2015]. https://www.e-tar.lt/portal/lt/lega1Act/TAR.91F3BE482534

14. Lietuvos urbanistinès politikos kryptys. Projektas [online, cited 31.10.2013]. http://www.am.lt/VI/files/0.363498001247711030.pdf

15. Meuser, P. Experiments with convention. European urban planning from Camillo Sitte to New Urbanism. in Krier, R. Town spaces. Basel: Birkhauser, 2006. pp. 248-265.

16. Miestų ir miestelių bendrujų planų rengimo taisyklès [online]. 2004-0507 Nr. D1-263 [cited 05.11.2015]. http://www.am.lt/VI/article.php3?article_id $=14029$
17. Nutarimas dèl Lietuvos Respublikos architektūros politikos krypčių aprašo patvirtinimo [online]. 2005-05-18 Nr. 554 [cited 31.10.2013]. https://www.e-tar.lt/portal/lt/legalAct/TAR.EC1FFB5925D6

18. Racine, F. Developments in urban design practice in Montreal: a morphological perspective. Urban morphology, Vol. 20(2) 2016, pp .122-137.

19. Scheer, B. C. The epistemology of urban morphology. Urban morphology, Vol. 20(1), 2016, pp. 5-17.

20. Schenk, L. Designing cities. Basics - principles - projects. Basel: Birkhauser, 2015.360 p.

21. Skripkiūnas, T. Kauno centrinès dalies urbanistinių kompleksų sistemos urbanistinè architektūrinė koncepcija / Urban Architectural Concept of System of Urban Complexes in the Central part of Kaunas [final work of master's studies of architecture, tutor D. Dijokienè]. Vilnius: VGTU 2014.

22. Sujetaitè, K. Neries slėnio urbanistinių mazgų sistema centrinèje Vilniaus dalyje / The Urban Cores System of the Neris River Valley in the Central Part of Vilnius [final work of master's studies, tutor S. Motieka]. Vilnius: VGTU 2016.

23. Trancik, R. Finding Lost Space. New York, Chichester, Weinheim, Brisbane, Singapore, Toronto: John \& Sons, INC., 1986. 246 p.

24. Vètè, A. Lietuvos miestu teritoriju bendruju planu erdvinès koncepcijos samprata praktikoje [manuscript]. Vilnius: VGTU 2016. 31 p.

25. Vètė, A. Miestų modeliavimas XX -XXI a. Lietuvos architektų urbanistų akimis Vakarų Europos kontekste. Science - Future of Lithuania. Vol. 8(1), 2016, pp. 65-76.

26. Vyšniūnas, A. Architektūra ir urbanistika. Sampratų ir žanrų pinklèse. Terra Urbana: urbanistinès kaitos žemélapiai [articles collection]. Vilnius: VDA 2013, pp. 25-42.

27. Vyšniūnas, A. Architektūros politika. Tarp Politics ir Policy. Miesto architektūra. Erdvès, formantai, akcentai [articles collection]. Vilnius: VDA 2015, pp. 53-70.

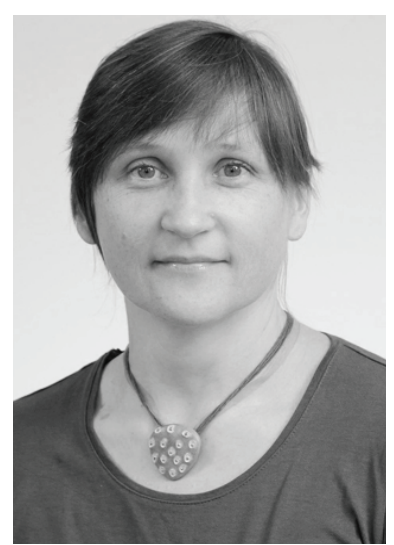

Dalia Dijokienė obtained B. arch. and M. Sc. Arch. from Vilnius Gediminas Technical University in 1995 and 1997 respectively. She received the degree of Doctor of Humanities in Architecture from VGTU in 2002. The theme of her PhD thesis was Historical Suburbs: Genesis, Development, Value, Maintenance (on the Example of Lithuanian Towns).

Since 2004 she has been an Associate Professor with the Department of Urban Design, Faculty of Architecture, Vilnius Gediminas Technical University and since 2013 - Head of the Department of Urban Design. In 2006-2016 she has been a guest lecturer at the Universities in Italy, Poland, Norway, the Netherlands. In 1999 she was an architect trainee at Lyngby, Denmark. From 1998-2007 she was an Architect with Closed Joint Stock Company "Atkirta UAB". Since 2007 she has been a free-lance architect. She is author and co-author of more than 30 architectural projects and has presented reports at 21 international and national conference. She is the author of 24 scientific publications: 8 of them are published in the national scientific journal "Town planning and architecture", the others are published in international scientific journals. Her recent research publications are:

- Dijokienè, D. Identified and modelled elements of urban fabric in academic works of students. City as organism. New visions for urban life. Rome: Sapienza University of Rome, 2016, pp. 1403-1410. ISBN 9788894118810; Dijokienè, D. Senamiesčių ir istorinių centrų rekonstravimas Lietuvoje: vertybiu nustatymas, metodiniai principai, pletros modeliavimas, Acta Academiae Artium Vilnensis. Miesto architektüra. Erdvès, formantai, akcentai. Vilnius: Vilniaus dailès akademijos leidykla, 2015, Nr. 76, pp. 119-131. ISSN 1392-0316, ISBN 9786094471742 [in Lithuanian];

- Dijokiene, D. Challenges of designing new urban quality in historical environment: based on final projects of BA students of the Department of 
Urban Design, FA, VGTU. Architecture and Urban Planning. Riga: Riga Technical University, 2013, Vol.8, pp. 60-64. ISSN 16914-333.

Her research interests are urban nuances of the town spatial expansion beyond the old town's borders, urban design and history of spatial development of towns. She is a member of the Second Immovable Cultural Heritage Assessment Board (Department of Cultural Heritage under the Ministry of Culture), since 2010, she has been specializing in architectural and urban immovable cultural heritage.

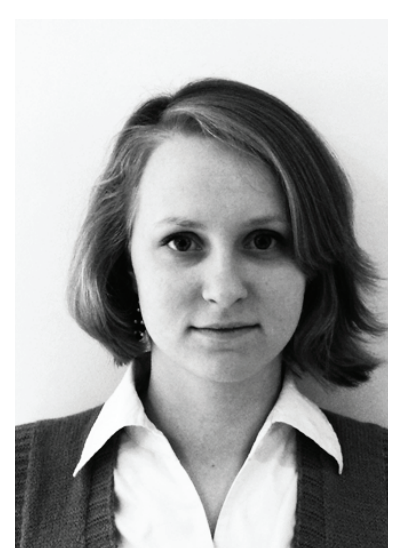

Agnè Vèté obtained B. arch. and M. Sc. arch. from Vilnius Gediminas Technical university in 2011 and 2013 respectively. The theme of her $\mathrm{PhD}$ thesis is The determination of town urban form and the valuable features identification model.

Since 2016 she has been a Lecturer with the Department of Urban Design, Faculty of Architecture, Vilnius Gediminas Technical University. Previously she was an Assistant with VGTU, a Trainee at VGTU and an Urban Designer with UAB "Archimes", where she specialized in urban research.

Her recent research publications are:

- Vèté, A. Miestų modeliavimas XX

-XXI a. Lietuvos architektų urbanistų akimis Vakaru Europos kontekste, ScienceFuture of Lithuania.Vilnius: VGTU, 2016,
- Ivanauskaitė, A.. Quality Living Environment: a Public or Private a Matter, Open Urban Studies and Demography Journal. Ljubljana: Bentham Open, 2015, Vol. 1, Suppl.1-M2, pp. 16-22. ISSN: 2352-6319 [in English]; - Ivanauskaite, A. Miesto urbanistinès formos samprata ir jos taikymo galimybės Lietuvoje, Science - Future of Lithuania. Vilnius: VGTU, 2015, T. 7, Nr. 1, pp. 46-54. ISSN 2029-2341 [in Lithuanian].

Her current research interests are urban design and planning - preservation of valuable features of urban form and visual identity during town and city modelling.

\section{Contact Data}

\section{Dalia Dijokienè}

Department of Urban Design, Faculty of Architecture of Vilnius Gediminas Technical University

Address: 26/1 Pylimo St., Vilnius, 01132, Lithuania

Phone: +37065067897

E-mail: dalia.dijokiene@vgtu.1t

\section{Agnè Vètè}

Department of Urban Design, Faculty of Architecture of Vilnius Gediminas Technical University

Address: 26/1 Pylimo St., Vilnius, 01132, Lithuania

Phone: +37061882300

E-mail: agne.vete@vgtu.lt

T. 8, Nr. 1, pp. 65-76. ISSN 2029-2341 [in Lithuanian]; 